\title{
Financial Accounting, Analysis and Features of Calculations With Personnel
}

\author{
Gulnara A. Gareeva ${ }^{1}$, Diana R. Grigoreva ${ }^{1} \&$ Ilnur I. Mahmutov ${ }^{1}$ \\ ${ }^{1}$ Department of Economics of Enterprises and Organizations, Faculty of Economics, Nabereznye Chelny, Kazan \\ Federal University, Kazan, Russia \\ Correspondence: Gulnara A. Gareeva, Candidate of Pedagogical Sciences, Associate Professor, Department of \\ Economics of Enterprises and Organizations, Faculty of Economics, Nabereznye Chelny, Kazan Federal University, \\ Kazan, Russia. E-mail: gagareeva1977@mail.ru
}

Received: August 8, 2020

Accepted: September 17, 2020

Online Published: October 4, 2020

doi:10.5430/ijfr.v11n5p221

URL: https://doi.org/10.5430/ijfr.v11n5p221

\begin{abstract}
One of the main factors of the effectiveness of the enterprise is the staff. Competent accounting and analysis of calculations with staff for other operations can significantly affect the final financial activities of any organization. The calculations with the staff are not a less important component of the final report of the organization, on the basis of which the profit is formed. All this leads to whether the company conducts effective financial activity or not. The organization's calculations with employees for other operations include payments for merchandise paid by it to merchants, for goods purchased by employees with payment by installments at the expense of the credit received by the organization in the bank, on loans issued to employees. It also involves payments for individual housing construction, the purchase or construction of garden houses, the acquisition of a household. The main aim is to recover material damage caused by an employee of the organization as a result of shortages and theft of monetary and material values and other types of damage. To achieve this goal, the following tasks were solved: the theoretical basis for accounting for loans granted, for material damage compensation was considered, the company was analyzed. In this paper, we consider the main aspects of the management of personnel by other operations, their competent accounting, as well as analysis based on the average statistical data of companies in Russia (Gareeva \& Grigoreva, 2019).
\end{abstract}

Keywords: other operations, settlements with personnel, loans, material damage

\section{Introduction}

Each company in its activities carries out calculations with staff not only for remuneration, accountable amounts but also for other operations. Other operations with staff include:

- Calculations for loans granted;

- Compensation for material damage;

- On technological violations;

- Payments for special clothes, vouchers, property sold on credit;

- Calculations for employee insurance contracts and other (Grigoreva et al., 2018).

To summarize information on settlements with the organization's personnel and accounting of all types of settlements with employees, except for payments for labor, settlements with accountable persons, and depositors, it is necessary to use account 73 "Calculations with staff for other operations". Account 73 takes into account, in particular, the calculations for loans, the calculations for damages resulting from shortages, damage (Grigoreva et al., 2019)

In order for the calculations with the staff for other operations to be correctly and timely reflected in the accounting, it is necessary to know not only the method of accounting for these operations (Devin et al., 2020), but also the criteria by which operations on calculations with personnel can be attributed to others Christensena, et al. 2019).

The purpose of this article is to study the accounting of settlements with personnel for other operations, theoretically and practically in the enterprise. According to the accounting policies of organizations, accounting for settlements with staff on other transactions is conducted on account 73, "Payments to personnel on other operations". The working plan of accounts provides for the opening of the following sub to the account 73 "Settlements with personnel for other 
operations" accounts:

1) "Calculations for loans granted";

2) "Calculations for the compensation of material damage";

3) "Calculations for vouchers"/

Analytical accounting for account 73 "Calculations with staff for other operations" should be maintained for each employee.

The debit of account 73 "Calculations for other operations" reflects the employee's debt to the company, the loan - the repayment of debt. In particular, the debit of account 73.1 "Settlements with staff for other operations" reflects the amount of the loan provided to the employee in correspondence with account 50 "Cashier" or 51 "Settlement Account".

\section{Methods}

Calculations of an organization with employees for other operations include payments for merchandise paid by it to merchants for goods purchased by employees with an installment payment due to a credit received by the organization in a bank; to recover material damage caused by an employee of the organization as a result of shortages and theft of monetary and material values and other types of damage.

For the account of calculations with personnel, the account 73 "Calculations with the personnel for other operations" is used. To account 73 "Settlements with personnel for other operations" can be opened sub. Accounts for types of calculations:

- 73-1 "Settlements for goods sold on credit";

- 73-2 "Calculations for loans granted";

- 73-3 "Calculations for compensation of material damage" and others.

Sat account 73-1 "Settlements for goods sold on credit" is used if the organization fully reimburses the merchants for the organizations of the loan provided to the employees of the organization at the expense of the bank loan (Kim et al., 2019).

Dt 73-1 "Payments for goods sold on credit"

Kt 93 "Loans of banks for employees"

Then, as the employee deducts from the employee's salary, his loan debt (debit 70, credit account 73-1) decreases, and the bank's loan is debited (debit 93, credit 51), (Dale et al., 2019).

From January 21, 1997, the material benefit from the loans received is included in the total annual income of employees of the organization. An example of the determination of material benefits is depicted in formula 1.

$$
\text { M.benefits }=\frac{2}{3} * \frac{\text { refinancing rate } * \text { the number of day sin the calculated period }}{100 * 360} * \text { outstanding loan balance }
$$

Material damage caused by an employee of the organization may be recovered at the book or market value of missing or damaged material assets. In the event of recovery of shortages and damage of material values at market prices in the accounting record is given:

Dt 73-3 - shortage and damage of material values at market prices;

Kt 84 - the book value of material values. 83-3 - the difference between the market and book value of material values (Sapfirova et al., 2019).

Material damage is compensated either by deduction from the salary, or by employee contributions to the cash desk or to the settlement account of the organization (debit accounts 50, 51, 70, credit account 73-3). The excess of the market value over the book value of the material values is attributed to the financial results of the company (debit 83-3, credit 80). This is related to the period in which the reimbursement of material damage was made.

\section{Results and Discussion}

In any organization for obtaining a loan, the employee writes an application for a loan. Then they send it to the director for consideration of this issue and decision making. The director considers the application of the employee, concludes a loan agreement with him (Salau et al., 2018). 
Repayment of the loan is carried out in equal parts:

1) making the repayment of the loan in the cash office of the company, which is issued a cash receipt.

2) withholding from the wages of an employee of the enterprise upon his written application.

Table 1 . The scheme of reflection of operations associated with the provision and repayment of the loan in monetary terms

\begin{tabular}{lllll}
\hline The content of the business transaction & Document & Amount, rub. & debit & credit \\
\hline $\begin{array}{l}\text { Issued from the cash loan to the employee under } \\
\text { the loan agreement }\end{array}$ & Account cash warrant & 20000,00 & $73-1$ & 50 \\
\hline Listed cash employee as a loan & Account statement & 10000,00 & $73-1$ & 51 \\
\hline $\begin{array}{l}\text { Made to the cashier the payment on the loan } \\
\text { provided }\end{array}$ & Cash Receipt Order & 2000,00 & 50 & $73-1$ \\
\hline $\begin{array}{l}\text { Withheld at the request of the employee from the } \\
\text { salary the amount of loan repayment }\end{array}$ & Payslip & 1000,00 & 70 & $73-1$ \\
\hline Accrued interest on the loan & $\begin{array}{l}\text { Accounting reference } \\
\text { calculation }\end{array}$ & 1000,00 & $73-1$ & $91-1$ \\
& & & & \\
\hline
\end{tabular}

According to the accounting policy of a standard enterprise, in order to ensure the accuracy of accounting data and financial statements, it conducts an inventory of property and financials.

The shortage of funds can be repaid:

- The introduction of funds into the cash desk of the organization, as evidenced by a cash receipt;

- Deductions from wages by order of the head, made by order of the head;

- Execution of court documents.

Table 2. The scheme of reflection of operations associated with the shortage of cash on hand, rub.

\begin{tabular}{llll}
\hline The content of the business transaction & Document & debit & credit \\
\hline Reflects the shortage of cash on hand & Inventory inventory & 94 & 50 \\
\hline Related shortage to the guilty person & Order & $73-2$ & 94 \\
\hline The amount of shortage is paid to the cashier of the enterprise & Cash Receipt Order & 50 & $73-2$ \\
\hline
\end{tabular}

Similarly reflects the posting on the lack of material values and fixed assets. The organization pays the cost of vouchers for the employees of the enterprise at the expense of the profit left to the organization after paying the profit tax, the employees themselves partially pay for the vouchers.

Table 3. The reflection of operations associated with the calculations for vouchers, rub.

\begin{tabular}{llll}
\hline The content of the business transaction & Document & debit & credit \\
\hline Purchased and paid for a sanatorium voucher & Payment order & $50-3$ & 76 \\
& & 76 & 51 \\
\hline Issued a voucher employee of the enterprise & Account cash warrant & $73-3$ & $50-3$ \\
\hline Partial cost of the voucher is reimbursed by the FSS & Accounting reference calculation & 69 & $73-3$ \\
\hline Paid by the employee of the partial cost of the permit & Cash Receipt Order & $50-1$ & $73-3$ \\
\hline Paid for the cost of the permit at their own expense & Accounting reference calculation & $91-2$ & $73-1$ \\
\hline
\end{tabular}


Thus, the accounting of settlements with personnel for other operations is conducted following the current legislation of the Russian Federation. An organization must have an approved accounting policy reflecting the accounting for settlements with personnel on other operations. Accounting for settlements with personnel for other operations is conducted on account 73 "Calculations with personnel for other operations", to which sub can be opened. accounts: calculations on loans granted; calculations for the compensation of material damage, calculations for vouchers.

\section{Summary}

The introduction of accounting automation will greatly facilitate the work with suppliers and goods. Accounting automation will significantly reduce the list of operations performed manually by an accountant. In addition, the automation of accounting will eliminate the risk of making mistakes when transferring data from one document to another, since each digital information is entered into the database only once (Kazutaka, (2012). The disadvantage of the accounting policy in relation to the method of accounting for settlements with staff for other operations is the lack of an approved schedule of workflow, as well as at this enterprise, there are no job descriptions for accountants (Christensena et al. 2019). The findings from the empirical data shows that automated accounting may lead to a decreased need of accounting consultants if the accounting firms do not extend or diversify their services. Moreover, advisory and analytical services will dominate the industry because automation will lead to more financial misstatements, which drives the need of analytical services. To comply with these changes, the future accounting consultant needs to possess more technical knowledge. The accounting consultant assistant will most probably be replaced by IT-consultants and in the long term, all consultants will be salespersons rather than accounting consultant. Regarding the attitude, the majority of the accounting consultants are positive towards automated accounting and their impacts, even though some tend to show a negative attitude to certain impacts. (Törnqvist, and Forss, 2018).

The appearance of these documents will significantly improve the work of any enterprise.

In order for the organization's activities to be conducted steadily towards improvement, the organization's personnel need to periodically confirm the level of their qualifications and learn new changes in their fields of activity (Frolova, 2010).

Also one of the ways to improve the organization of accounting for settlements with staff may be a process of more automated accounting of calculations, which will improve the verification and control of primary documents for accounting of transactions related to the necessary operations (Ivanova, 2018).

Thus, accounting at the company is conducted according to all the rules, and there are no problems in this area. However, the proposals listed above will help to create more comfortable conditions for the work of accountants, slightly improve the efficiency of bookkeeping, and strengthen its reliability.

\section{Conclusion}

The results of the analysis allow us to draw the following conclusions:

1. In the chart of accounts for accounting, a special section has been created for settlements with personnel for other operations, including:

- Calculations for loans granted;

- Calculations for the compensation of material damage.

The company undertakes to be an intermediary between workers and employees and third parties, organizations (on the writ of execution, for goods sold on credit, on loans to young families, on the construction of garden houses), conducts calculations for the compensation of material damage, etc.

Account 73 - active-passive, debit balance reflects the amount of debt of employees to the enterprise for outstanding loans.

2. As a result of the study, the peculiarities of accounting for this account were identified. In particular - on the sub. Account 73-1 "Settlements for loans granted" reflects settlements with employees of an enterprise on loans granted to the. For the amount of payments received from the employee-borrower, account 73 "Settlements with staff for other operations" is credited in correspondence with accounts 50 "Cashier", 51 "Settlement account", 70 "Calculations with staff on remuneration" (depending on the accepted order of payment).

On the sub. account 73-2 "Calculations for the compensation of material damage" takes into account calculations for the compensation of material damage caused by an employee of the enterprise as a result of shortages and theft of cash and inventory, damage, as well as compensation for other types of damage.

3. The paper provides recommendations for conducting analytical accounting on account 73-2 "Calculations on 
compensation for material damage", the correctness of the accounting entries on this account and the correspondence of analytical accounting records on account 73-2 to entries in journal-order No. 8, the general ledger and balance.

\section{Acknowledgments}

The work is performed according to the Russian Government Program of Competitive Growth of Kazan Federal University.

\section{References}

Christensena, M., Skærbæk, P., \& Tryggestad, K. (2019). Erratum to "Contested organizational change and accounting in trials of incompatibility". Management Accounting Research, 45, 3-5. https://doi.org/10.1016/j.mar.2019.03.001

Dale, A. M., Enke, C., Buckner-Petty, S., Hipp, J. A., Marx, C., Strickland, J., \& Evanoff, B. (2019). Availability and use of workplace supports for health promotion among employees of small and large businesses. American Journal of Health Promotion, 33(1), 30-38. https://doi.org/10.1177/0890117118772510

Devin, S. P., Ara, O. F., \& Jafari, M. (2020). The Impact of Loans to Deposit Ratio (LTD) and Return on Assets (ROA) on the Capital Adequacy Ratio of the Tehran Stock Exchange and OTC. Journal of Management and Accounting Studies, 8(1), 51-56.

Frolova, T. (2010). Account of settlement operations (p. 192). Lecture notes. Taganrog / Tit Sfu.

Gareeva, G. A., \& Grigoreva, D. R. (2019). Integrated method for effective management in telecommunication services. International Journal of Economic Perspectives, 11(4), 464-473.

Grigoreva, D. R., Basyrov, R. R., \& Mukhametdinov, M. M. (2018). Justification of directions of research for ensuring environmental indicators of energy installations of transport purpose.

Grigoreva, D. R., Gareeva, G. A., \& Mikrukova, V. S. (2019). The role of outsourcing accounting at a small enterprise / ad alta. Journal of Interdisciplinary Research, 9(9), 35-38.

Ivanova, O. (2018). Accounting for small businesses. Textbook / Rior Ltd, 172, 98-102.

Kazutaka, K. (2012). Roles of Participatory Action-oriented Programs in Promoting Safety and Health at Work. Safe Health Work, 3, 155-165. https://doi.org/10.5491/SHAW.2012.3.3.155

Kim, D., Park, K., Park, Y., \& Ahn, J. H. (2019). Willingness to provide personal information: perspective of privacy calculus in iot services. Computers in Human Behavior, 92, 273-281. https://doi.org/10.1016/j.chb.2018.11.022

Salau, O., Osibanjo, A., Adeniji, A., \& Igbinoba, E. (2018). An integrated dataset on organisational retention attributes and commitment of selected ict and accounting firms. Data in Brief, 18, 1930-1936. https://doi.org/10.1016/j.dib.2018.04.140

Sapfirova, A. A., Volkova, V. V., \& Petrushkina, A. V. (2017, December). Information technologies and information compliance in labor relations: legal regulation and prevention of violations of labor rights. In perspectives on the use of new information and communication technology (ict) in the modern economy (pp. 911-916). Springer, cham. https://doi.org/10.1007/978-3-319-90835-9_102

Törnqvist, E., \& Forss, L. (2018). Automated accounting in accounting firms: A qualitative study on impacts and attitude. Umeå School of Business and Economics (USBE).

\section{Copyrights}

Copyright for this article is retained by the author(s), with first publication rights granted to the journal.

This is an open-access article distributed under the terms and conditions of the Creative Commons Attribution license (http://creativecommons.org/licenses/by/4.0/). 